WWW.iibpas.com

\title{
ROLE OF DHATVAGNI IN ATTAINING DHATUSARATA - AN AYURVEDIC REVIEW
}

\section{TANK KN ${ }^{1}$ AND NIKHATE SP $^{2 *}$}

1: PG Scholar, Department of Kriya Sharira, Parul Institute of Ayurved

2: Guide, Associate Professor, Department of Kriya Sharira, Parul Institute of Ayurved

*Corresponding Author: Nikhate SP; E Mail: dr.spnikhate@gmail.com

Received 12 ${ }^{\text {th }}$ Dec. 2021; Revised $14^{\text {th }}$ Jan. 2022; Accepted $7^{\text {th }}$ Feb. 2022; Available online $5^{\text {th }}$ March 2022

https://doi.org/10.31032/IJBPAS/2022/11.3.1067

\begin{abstract}
Ayurveda is a traditional indian science of life which aims to maintain health of healthy person and treat the person with disease. As foretold by Ayurveda Acharyas Dosha, Dhatu, Mala are the basic factors of living body. Dhatu the is structural units of body which provides strength and nourishment. There are seven Dhatus explained by Ayurved acharyas that are Rasa, Rakta, Mamsa, Meda, Asthi, Majja and Shukra. Sara is meant by Vishuddhatar Dhatu i.e., the essence of Dhatu is termed as Dhatu Sara. Dhatu Sarata is helpful in assessing functional as well as qualitative assessment of Dhatus. Acharya Charaka has explained eight types of Sarata that are Twaka Sara, Rakta Sara, Mamsa Sara, Meda Sara, Asthi Sara, Majja Sara, Shukra Sara and Sattva Sara.

Dhatu sarata relies upon many factors in digestion. Dhatvagni plays vital role in production of Dhatu. Dhatvagni plays role in assimilating or synthesizing Dhatu of living body. Dhatvagni is seven in number respective to each Dhatu namely - Rasagni in the Rasa Dhatu, Raktagni in the Rakta Dhatu, Mamsagni in the Mamsa Dhatu, Medagni in the Meda Dhatu, Asthyagni in the Asthi Dhatu, Majjagni in the Majja Dhatu, Shukragni in the Shukra Dhatu.
\end{abstract}

\section{Keywords: Dhatusarata, Dhatvagni, Srotas, Sarata}

\section{INTRODUCTION}

Ayurveda is science of life which comprise of all the factors which are absolute or accessory in the determination of health.
Ayurveda has described three foundation factors of body which are dosha, dhatu and mala. Dosha is functional unit. Whereas 
dhatus are structural unit of human body. According to ayurveda science the equilibrium of dosha, dhatu and mala is the cause of a person's good health. Dhatus are seven in number. Increase or decrease in the quantity of dhatus leads to diseased condition. When Dhatu is in its purest form or the essence of dhatu is known as Dhatusarata, this condition exhibits the strength \& vitality in human body. The nourishment of all Dhatus is influenced by the function of respective Dhatvagni. To motivate the formation of self-clone of respective tissue and depended tissues (Upadhatus) are major functions of each Dhatvagni.

\section{Aims and objective}

- To study the concept of Dhatusarata

- To study the concept of Dhatvagni

- To understand the role of Dhatvagni in attaining Dhatusarata

\section{MATERIALS AND METHOD}

- Literature available from various Ayurvedic Samhita and its commentary.

- Research papers and articles related to subject.

\section{REVIEW \& DISCUSSION}

\section{Dhatusarata}

Dhatus are body constituents which build the basic structure and carry various physiological functions. They work as body tissues to stabilize and sustain body. The word 'Dhatu' is derived from the word root "Dha" by adding suffix "Tun". It means that which sustains and nourishes. Acharya Susruta defines about dhatu as - "ta ete sarira dharanat dhatavah ityuchynte". Dhatus are seven in number - Rasa, Rakta, Mamsa, Meda, Asthi, Majja and Shukra. The balanced condition of all dhatus is called swasthya or health. If the dhatus get decreased or increased in quantity, they cause various disease in human body.

Dhatu sarata is very important concept of Ayurveda which is described as one of the Dashvidha parikshya bhava as enumerated by acharya Charak. Sara is defined as the purest form of dhatu. Definition of Dhatusarata given by Acharya Chakrapani is as -

"vishudhataro dhatu sara ucchyate"

Sara is described as of eight kinds in relation to skin, blood, muscles, fat, bone, bone marrow, semen and mind. Each succeeding one is better than its proceeding and helpful in determining the degree of strength.

Sara is also mentioned in Atura Pariksha by Acharya Charak, which is classified as sarvasara, madhyama sara and avara sara. Here Sarvasara is not a separate type, but it is just a stage which is found in a person in the form of qualitative \& quantitative presence of all the types of Sara \& gives 
the information about Dehabala. Sara pariksha is one of important tool described to determine bala (strength) of the person. Acaharya Charaka emphasized that strength cannot be correlated with mass or the physique of the body i.e., well built \& lean stature. It would be a misleading notion if the physician considers a wellbuilt person to be having good strength, merely based on his physique or a lean person can always to be considered as weak as contrary condition may exist e.g., a lean built person may be possessing good strength. This is explained with the analogy of ants which though having tiny body are able to carry heavy weights due to its strength. In order to avoid such misinterpretation sara pariksha should be done. Various acharya have described different types of Dhatu sarata.

\begin{tabular}{|c|c|c|c|c|c|c|}
\hline S. No. & $\begin{array}{c}\text { Charak } \\
\text { Viman 8/102 }\end{array}$ & $\begin{array}{c}\text { Sushruta } \\
\text { Sutra } \\
\mathbf{3 5 / 1 6}\end{array}$ & $\begin{array}{c}\text { Astanga } \\
\text { Sangraha } \\
\text { Sharir 8/32 }\end{array}$ & $\begin{array}{c}\text { Astanga } \\
\text { Hridya } \\
\text { Sharir3/117 }\end{array}$ & $\begin{array}{c}\text { Kashyapa } \\
\text { Sutra } \\
\mathbf{2 8} / 37\end{array}$ & $\begin{array}{c}\text { Brihat } \\
\text { Samhita } \\
96 / 68\end{array}$ \\
\hline 1 & Twaksara & Satvasara & Twaksara & Twaksara & Twaksara & Medasara \\
\hline 2 & Raktasara & Shukrasara & Raktasara & Raktasara & Raktasara & Majjasara \\
\hline 3 & Mamsasara & Majjasara & Mamsasara & Mamsasara & Mamsasara & Twaksara \\
\hline 4 & Medasara & Ashtisara & Medasara & Medasara & Medasara & Asthisara \\
\hline $\mathbf{5}$ & Asthisara & Medasara & Asthisara & Asthisara & Astisara & Shukrasara \\
\hline $\mathbf{6}$ & Majjasara & Mamsasara & Majjasara & Majjasara & Majjasara & Rudhirsara \\
\hline 7 & Shukrasara & Raktasara & Shukrasara & Shukrasara & Shukrasara & Mamsasara \\
\hline $\mathbf{8}$ & Satvasara & Twaksara & Satvasara & Satvasara & Ojahsara & \\
\hline $\mathbf{9}$ & ---------- & ----------- & ----------- & -------- & Satvasara & \\
\hline
\end{tabular}

\section{Dhatvagni}

"Agni" is Sanskrit word which means fire.

In Ayurvedic science Agni is defined as the fire element which is present in human body at microscopic level. Agni is responsible converting food into energy. Agni is derivative of Tejas Mahabhuta. There are thirteen types of Agni as mentioned by Ayurveda acharya.

\begin{tabular}{|c|c|}
\hline & \\
\hline 1-Kosthagni & Jatharagni \\
\hline \multirow{4}{*}{ 3-Bhutagni } & Akashiya Agn \\
\hline & $\begin{array}{c}\text { Vayviya Agni } \\
\text { Taijas Agni }\end{array}$ \\
\hline & Apya Agni \\
\hline & Parthiva Agni \\
\hline \multirow{7}{*}{ 7-Dhatvagni } & Rasagni \\
\hline & Raktagni \\
\hline & Mamsagni \\
\hline & Medagni \\
\hline & Asthyagni \\
\hline & Majjagni \\
\hline & Sukragni \\
\hline
\end{tabular}


The Agni which is responsible for nourishment for seven dhatus is known as Dhatvagni. After the completion of Jatharagni \& Bhutagni Vyapara, Dhatvagni plays important role in production of Dhatu. Ahara rasa spread due to Vyana vayu (vikshepana) in particular Dhatu places (srotasa) upon which Dhatvagni acts \& produces two main parts named sthulabhaga (poshya) \& sukshmabhaga (poshaka). Out of them sthulabhaga is used to nourish the particular dhatu, whereas Sukshmabhaga is further used to nourish next Dhatu. Again, this Agni performs specific action on its own nutritive part i.e prasadabhaga. During the process of own nourishment, it also gives nourishment to its Upadhatu. For example, Rasadhatvagni plays an important role in the formation of Rakta Dhatu from Rasa Dhatu which further nourishes the Mamsa Dhatu by the influence of Raktadhatvagni. Whenever potency or quality of any level of Dhatvagni diminishes or elevates the further procedure of production of next Dhatu may be affected. During this process, some metabolic wastes are produced which are known as Dhatumala.

\section{Srotas}

Dictionary meaning of word 'Strotas' are read as -a current, a stream, a river. The word srotas is etymologically derived from the Sanskrit root 'Stru-Strabane' dhatu which has different meanings - exudation, oozing, filtration, permeation, to flow, to move, etc. Srotas is meant to carry dhatu in stage of metabolism. Each dhatu has its own channel of metabolism. After digested by agni, Ahararasa along with rasa reaches srotas of each dhatu. Dhatvagni is located in respected srotas of particular dhatu. It means that during process of metabolism, one dhatu gets transformed into further dhatu in strotas.

Srotas acquires colour and shape as per Dhatu it produces and is named after that dhatu. These body spaces are meant especially for production of all entities. These basically are channels, which absorb nourishment from gastro intestinal tract; convey it to Agni lodged in srotas i.e., Dhatvagni and then give rise to respective Dhatus for which they are meant. Not only this, srotas also are responsible to transport the products, to desirable place.

\begin{tabular}{|c|c|c|c|c|}
\hline \multirow[t]{2}{*}{ S. No. } & \multirow[t]{2}{*}{ Name of srotas } & \multicolumn{3}{|c|}{ Mulasthana } \\
\hline & & Charak Samhita & Sushrut Samihita & Ashtang Samgrah \\
\hline 1. & Rasavaha & $\begin{array}{c}\text { Hrdya and Dasa } \\
\text { dhamani }\end{array}$ & $\begin{array}{c}\text { Hrdya and rasavahi } \\
\text { dhamani }\end{array}$ & $\begin{array}{c}\text { Hrdya and dasa } \\
\text { dhamani }\end{array}$ \\
\hline 2. & Raktavaha & Yakrta and pliha & Yakrta and pliha & Yakrta and pliha \\
\hline 3. & Mamsavaha & Snayu and twak & Snayu and twak & Snayu and twak \\
\hline 4. & Medovaha & Vrkka and vapavahan & Vrkka and $k a t i$ & Snayu and mamsa \\
\hline$\underline{5 .}$ & Asthivaha & Jaghana and meda & - & Jaghana and meda \\
\hline$\underline{\underline{6}}$ & Majjavaha & Asthi and sandhi & - & Parva and asthi \\
\hline 7. & Shukravaha & Vrshana and sepha & Vrshana and stana & mushka and stana \\
\hline
\end{tabular}




\section{CONCLUSION}

Dhatu sarata is a concept which is described in Ayurved. Each succeeding dhatu one, better than its proceeding and helpful in determining the degree of strength. The person who is endowed with all types of excellences, will be very strong, with very stable physique, capable of withstanding strain, having full self confidence in result of all his activities, generous in all his deeds, possesses a strong body, balanced gait, has vibrating, polite, dignified and loud voice, enjoys happiness, wealth, money, luxuries, and respect; is endowed with many children of similar qualities and enjoys long life. To attain dhatusarata many factors are responsible including dhatvagni. Proper dhatvagni will lead to proper formation of dhatus. If Dhatvagni is impaired proper dhatu formation would not take place. Hence, dhatvagni plays important in attaining dhatusarata.

\section{REFERENCES}

[1] Monier William, Sanskrit-English Dictionary, 2006, p.513

[2] Agnivesh; Charaka Samhita revised by Charaka \& Dridabala; with Ayurveda Dipika commentary by Chakrapanidatta; edited by $\mathrm{Dr}$ Ganga SahayePandeya; Foreword by Vaidya YadavjiTrikamji Acharya; 6 th edition 2000; published by Choukhambha

Sanskrit Sansthan, Varanasi.

[3] kashyap Samhita with English translation (Vrddhajivakiya Tantra) by Pandit Hemraj Sharmana, Published by Chaukhamba Sanskrit Sansthan

[4] Sushruta Samhita with English translation of text and dalhans commentary along with critical notes edited and translated by Priyavat Sharma, published by chaukamba visva bharti 2004.

[5] Varahamihir's Brihat Samhita by pandita Bhushana V. Subramanya Sastri, translated and published by Vidhwan M. Ramakrishna Bhat, Printed by V.B. Soobbiah \& Sons, Banglore City

[6] Charaka S, Sashtri Kashinath, Pt, Chaturvedi Gorakhnath., Dr. Ibid verse 15/4. Varanasi: Chaukhamba Bharti Academy; 2004.

[7] Sushrut Samhita, Shastri Ambicadutt., Dr. Varanasi: Chaukhamba Sanskrit Sansthan; 2005

[8] Sarira kriya vidnana, a text book of physiology in ayurveda by nandini dilip dhargalkar, published by Chaukhamba Sanskrit Sansthan; 2015 
[9] A text book of Kriya Sharira by Prof. Dr. Subhash Ranade, Prof. Dr. R.R. Deshpande, published by Chaukhamba Sanskrit Sansthan; 2016 edition

[10] Jagruti Namdevrao Chaple; Ayurvedic aspect of Dhatu Sarata and its Application September 2018, Int J Ayu Pharm Chem 2018 Vol. 9 Issue 2

[11] Ghate, Umesh Shivajirao; Study of concept of Dhatu Sarata and its correlation with Ergography. 